Multilingua, 19(1-2): 97-124, 2000.

\title{
The sociolinguistic stratification of Hungarian in Subcarpathia ${ }^{1}$
}

\author{
István Csernicskó \\ Subcarpathian Hungarian Teacher Training College, Ukraine, \\ and Eötvös Loránd University, Hungary \\ and \\ Anna Fenyvesi \\ József Attila University, Hungary, and University of Pittsburgh, USA
}

\begin{abstract}
The minority Hungarians of Subcarpathia (Ukraine) have been regarded as a linguistically homogeneous community whose Hungarian language use is affected by their contact with Russian and Ukrainian in a uniform manner. This study demonstrates that such a view cannot be upheld in the light of quantitative empirical findings, which show Subcarpathian Hungarians to be a sociolinguistically stratified group of speakers whose Hungarian language use varies in a systematic manner according to sex, age, level of education, and place of residence. The paper also outlines some of the main differences in the language use of Hungarians in Subcarpathia and Hungary which are manifested in statistically significant ways.
\end{abstract}

\section{INTRODUCTION}

Following World War I, millions of ethnic Hungarians found themselves outside the political border of Hungary and became citizens of other countries, namely Yugoslavia, Romania, the Soviet Union, Czechoslovakia, and Austria. Even though many have chosen to re-emigrate to Hungary in the past eight decades, communities numbering hundreds of thousands - or, in the case of Romania, millions - of Hungarians have remained in these countries and have been living in bilingual or multilingual settings ever since. Their language use and the growing sociolinguistic and linguistic effects of bilingualism have never been empirically, or even just systematically, studied. Under the four decades of communism after World War II, the study or sometimes even the mention of Hungarian minorities was taboo, and linguistic research was not made possible until after 1989. In the years since the collapse of the communist regime, sociolinguistic and linguistic information about Hungarians outside Hungary has become increasingly more available, although even today only a limited range of sources exists, especially in English (see Beregszászi 1995/1996, Kontra 1995a, Fenyvesi 1995, Lanstyák \& Szabómihály 1996).

In the present paper we present the findings of a survey of Hungarian language use in Subcarpathia (Ukraine), which is part of a larger research project describing the sociolinguistics of Hungarian language use in countries neighboring Hungary. We discuss empirical, quantitative data that demonstrates differences in language use between the Hungarian varieties spoken in Hungary and in Subcarpathia which point to a case of dialect divergence (Auer \& Hiskens 1996: 15).

Our most important findings are that the Hungarian community in Subcarpathia is not homogeneous in its language use, as previously claimed, and that the linguistic effects of bilingualism are not uniform across the members of this community.

\section{THE HUNGARIANS OF SUBCARPATHIA}

Subcarpathia is the southwesternmost tip of Ukraine, situated between the divide of the Carpathian mountains and the national borders of Poland, Slovakia, Hungary, and 
Romania. It has traditionally been a multilingual and multiethnic region where Hungarians, Ukrainians, Russians, Ruthenians, Romanians, and Gypsies have lived together for centuries. It formed an integral part of Hungary until 1920 when, under the Treaty of Trianon, it first became part of Czechoslovakia, then, during World War II was readjoined with Hungary, and after the war it became part of the Ukrainian Soviet Socialist Republic. Finally, in 1991, Subcarpathia became part of the independent Ukraine. It is now one of Ukraine's 25 counties with a territory of 12800 square kilometers, approximately the size of Connecticut (Magocsi 1996: 525). According to the figures of the latest, 1989, census, 156 thousand people, or $12.5 \%$ of the total population of Subcarpathia, are of Hungarian nationality, while 168 thousand (or 13.3\%) claim to have Hungarian as their first language (Botlik \& Dupka 1993: 284). Thus, over $95 \%$ of Ukraine's total 163 thousand inhabitants of Hungarian nationality live in Subcarpathia (Shamshur \& Izhevskaya 1993: 166), the vast majority of them, $89 \%$, in the administrative districts around the four bigger towns - UŽhorod/Ungvár, Mukačevo/Munkács, Berehove/Beregszász, and Vinogradiv/Nagyszõlõs - stretching along the Hungarian-Ukrainian border (Magocsi 1996: 526). (Names of Subcarpathian towns and villages are given first transliterated, in their official Ukrainian versions, and second, in their traditional Hungarian forms throughout this paper.)

\section{THE STUDY}

The range and depth of the existing linguistic descriptions of Hungarian language use in Subcarpathia is rather uneven. Relatively ample information is available about the traditional dialects of the region (e.g. Horváth 1976, Lizanec ${ }^{2} 1992$ and 1996, etc.). Some descriptive work has been done on various professional and social registers (for instance, Györke 1991), and recently a volume discussing practical language cultivation issues directed at minority Hungarian speakers has been published (Kótyuk 1995). However, even though the Hungarians of the Subcarpathian region have lived in a multilingual environment for centuries, there is almost no information available on how this multilingualism has affected Hungarian language use in this area. For instance, the differences in Hungarian language use between Hungary and Subcarpathia have not been described to date, and no study has even yet attempted to show the extent to which such differences exist. Similarly, we know of no study that has aimed at revealing what social characteristics/variables determine various aspects of this Hungarian language use in the Subcarpathian Hungarian community. No mention was even made of the bilingualism of Subcarpathia's minority Hungarians in a recently published comprehensive reference book on European language contact situations, Goebl et al. (1997). (For a discussion of the reasons for the absence of such work, see Csernicskó 1997a.)

In the present paper we discuss a number of differences that we have found exist in the language use of Hungarians in Subcarpathia as compared with those in Hungary. On the basis of an empirical survey conducted among Hungarians in Subcarpathia, we identify patterns in their language use and thereby demonstrate that social stratification exists in the Hungarian language use within this region. The study presented in this paper is part of a larger research project, The Sociolinguistics of Hungarian Outside Hungary, describing both the sociolinguistic situation of minority Hungarians in countries neighboring Hungary in general and the stratification in language use among Hungarians in these countries (Kontra 1998).

Our survey was carried out in Subcarpathia in the summer of 1996 on a sample of 144 adult minority Hungarians stratified for age, education and settlement type. Data was gathered (concerning language use and linguistic attitudes) on 324 sociolinguistic variables and on 60 linguistic variables. The subjects, slightly fewer men than women (71 and 73 subjects, respectively), were chosen to represent three age groups (ages 18-27, 32-52, and 60- 
81 , with 48 subjects, or $33.3 \%$ of the total, in each group), two different levels of education (elementary school educated vs. college educated, that is, with 8 vs. over 14 years of schooling, ${ }^{3}$ and with 76 subjects or $52.8 \%$ in the former group and 68 subjects or $47.2 \%$ in the latter), and four settlement types (towns vs. villages each with a majority vs. minority of Hungarian residents). ${ }^{4}$ The four settlement types were represented by the Hungarian-majority town of Berehove/Beregszász (37 subjects, or 25.7\%), the Hungarian-minority town of UŽhorod/Ungvár (36 subjects, or 25\%), the Hungarian-majority village of Esen'/Eszeny (36 subjects, or 25\%), and the Hungarian-minority villages of Rakošino/Beregrákos and Kholmok/Kincseshomok (35 subjects, or 24.3\%). ${ }^{5}$ (We had to collect data in two places for the last settlement type, since in these villages where Hungarians form a minority within the population of the village, we were not able to find enough subjects in only one place.)

Linguistic and sociolinguistic data were gathered from the subjects in meetings where the field worker met with the subjects individually and asked them to fill out a questionnaire.

We used the 'friend of a friend method' (Milroy 1980) to select the subjects that would fit our predetermined social categories. In every case the field worker was a member of the community under investigation, thus satisfying the requirement proposed by Poplack (1993: 260) that in investigations of bilingual communities data be collected by individuals who are members of the given community and are considered as such by the other members, and whose linguistic repertoire contains the linguistic features under investigation.

In the questionnaire, questions about sociolinguistic information were asked concerning the social and linguistic background of the subjects, their use of languages spoken by them in the various domains, and their attitudes to the three languages of the community, Hungarian, Russian, and Ukrainian. Linguistic questions targeted the linguistic features of the Hungarian used in Subcarpathia.

The part of the questionnaire eliciting linguistic information contained a total of 69 questions requiring answers in one of 5 different task types covering 60 linguistic variables. The five tasks were the following:

- 1. Grammaticality judgments, sentence selection. The subject had to decide which one of two provided sentences s/he considered more acceptable;

- 2. Grammaticality judgments, sentence correction. The subject had to decide whether s/he regarded a sentence as acceptable or not, and if not, provide a correction of it;

- 3. Fill in the blanks, lexical. The subject had to fill one of two appropriate words or phrases provided into a sentence with a blank;

- 4. Fill in the blanks, inflectional. The subject had to use one of two choices of case endings provided for a given lexical item to fit into a sentence;

- 5. Fill in the blanks, profession name. The subject had to use a profession name whose meaning would fit a given sentence.

As part of The Sociolinguistics of Hungarian Outside Hungary project, the same questionnaire was administered to Hungarians in Slovakia, Romania, Yugoslavia (Serbia), Slovenia, and Austria, in order to allow for a cross-regional comparison of the Hungarian language use by minority Hungarians in these countries. The questionnaire method of data collection was chosen because it provided an equal amount of comparable data from the various groups of Hungarians. In order to make a comparison possible between the minority Hungarian groups and Hungarians in Hungary, the same questionnaire was also administered to a sample of 107 monolingual Hungarians from three villages, Ikrény, Veresegyház, and Szatymaz. ${ }^{6}$ The data from the survey was computerized with the help of the MEDIT coding program and statistically analyzed with the statistical software MINISTAT (Vargha 1996 and 1997).

The 60 linguistic variables targeted in the survey are of three kinds - we follow Lanstyák \& Szabómihály (1996), a study on Hungarian as spoken in Slovakia, in classifying 
the linguistic variables as belonging to one of the three groups. First, we refer as Universal (U) variables to the four variables that we believe to occur in the entire Hungarian speech community, in both Hungary and outside Hungary. These, typically, have a variant that is accepted as the Standard Hungarian variant, and one that is considered nonstandard. Second are those variables that, again, occur both inside and outside Hungary but whose nonstandard variants are phenomena that have parallels in Indo-European, and especially Slavic languages and, therefore may be more frequent in the Hungarian used in areas where it is in contact with these languages, like in Subcarpathia. Because they occur universally in the Hungarian speech community but their use is reinforced in situations of more intense language contact such as that in Subcarpathia, we call these Universal Contact (UC) variables, of which eight are discussed in our paper - these variables occur inside Hungary as a result of the overall influence of Indo-European languages. And, finally, the third kind of variables are the forms that are not present as variables inside Hungary but occur as such in Subcarpathia, and one variant of which is the Standard Hungarian realization (the only form that exists in Hungary), while the other would constitute a nonstandard form in Hungary (a form which is most likely the result of borrowing from Ukrainian and/or Russian) - we discuss four such variables and use the label Contact (C) variables for them.

\section{HYPOTHESES}

The basic premise of the whole of The Sociolinguistics of Hungarian Outside Hungary project has been that there are differences between the Hungarian language use of monolingual Hungarians in Hungary and that of Hungarians living in bilingual environments outside Hungary. The three hypotheses concerning the linguistic variables that were formulated for the project as a consequence of this are the following:

- Hypothesis A. There is a quantifiable difference in the acceptance of nonstandard forms in the two regions due to the fact that, as discussed above, the nonstandard variants of most of the variables are either contact features, or can be expected to become more frequent in a situation of language contact. More specifically, we expect to find a higher rate of acceptance of the nonstandard variants in Subcarpathia than in Hungary;

- Hypothesis B. Subjects from Hungary and subjects outside Hungary judge the nonstandard variants of the three kinds of variables ( $\mathrm{U}, \mathrm{UC}$, and $\mathrm{C}$ ) differently - for instance, it might be the case that monolingual Hungarians reject nonstandard variants that are purely contact features to a greater extent than do Hungarians outside Hungary;

- Hypothesis $C$. Across both areas, a statistically significant correlation exists between a number of social variables (such as age, sex, education, and settlement type) and the acceptance of the variants of the linguistic variables.

\section{FINDINGS}

In this paper we present our findings on 16 linguistic variables - morphological, morphosyntactic, and lexical - which are discussed below under the headings of seven linguistic phenomena: the indicative and imperative of $t$-final verbs, compounds, synthetic versus analytical constructions, singular and plural of nouns, agreement of nouns, feminine forms of profession nouns, and calques.

\subsection{The indicative and imperative of $t$-final verbs}

In Standard Hungarian, the present tense definite conjugation ${ }^{7}$ indicative paradigm of verbs ending in $-t$ is distinct from and has no homonymous forms with the definite conjugation forms in the imperative of these verbs. However, in some of the traditional regional dialects, those spoken in Subcarpathia among them (Lizanyec \& Horváth 1981: 17), and in nonstandard Hungarian, the imperative forms of $t$-final verbs are used in the indicative 
as well, resulting in a morphological merger of the two paradigms in the definite conjugation. A universal Hungarian feature (and so, in our terms, a Universal variable), such usage is very heavily stigmatized as uneducated in Hungarian (Kontra 1995b, and Váradi \& Kontra 1995) and most strongly discouraged by prescriptive literature on usage both in Hungary (Grétsy \& Kovalovszky 1983: 618) and in Subcarpathia (see, for instance, Balogh 1991, Horváth 1991, and Kótyuk 1995: 46-47).

In our survey we used two items to elicit the forms in question: one for verbs ending in a vowel and - $t$, válogat 'choose' in sentence 1 below, and one for verbs ending in an obstruent and - $t$, halaszt 'postpone' in sentence 2. Subjects had to fill in a verb ending that they considered appropriate in the following two sentences: ${ }^{8}$

(1) Ha Péter rossz-ul váloga meg a barát-ai-t,

if Peter bad-ESS choose_ PFX the friend-POSS.3SG-ACC discomfited jár.

go.INDEF.3SG

'If Peter chooses his friends badly, he'll soon be discomfited.'

(2)

Mi-nek ez a halogatás? Nem szeret-em, ha valaki

what.DAT this the delay not like.DEF.1SG if somebody

el-hala__ a döntés-ek-et.

PFX-postpone__ the decision-PL-ACC

'Why this delay? I don't like it when somebody postpones making decisions.'

In the two sentences, the verbs with the standard indicative endings are válogatja (choose.DEF.3SG) and elhalasztja (PFX.postpone.DEF.3SG), while the nonstandard options are válogassa (choose.IMP.DEF.3SG) and elhalassza (PFX.postpone.IMP.DEF.3SG), respectively. (In the imperative forms of $t$-final verbs the stem-final $t$ undergoes complete assimilation.)

Table 1. The choice of standard versus nonstandard indicative forms of $t$-final verbs among speakers in Subcarpathia and in Hungary.

\begin{tabular}{||c|c|c||}
\hline & $\begin{array}{c}\text { Subcarpathia } \\
(\mathrm{N}=144)\end{array}$ & $\begin{array}{c}\text { Hungary } \\
(\mathrm{N}=107)\end{array}$ \\
\hline Sentence 1: standard (válogatja) & $78.3 \%$ & $96.0 \%$ \\
nonstandard (válogassa) & $21.7 \%$ & $4.0 \%$ \\
\hline Sentence 2: standard (elhalasztja) & $47.9 \%$ & $91.5 \%$ \\
\hline
\end{tabular}

Sentence 1: The Chi-square test shows the difference to be significant $\left(\chi^{2}=15.12372 ; p=.0001\right)$

Sentence 2: The Chi-square test shows the difference to be significant $\left(\chi^{2}=33.93573 ; p=.000001\right)$ 
The results for the two sentences are shown in Table 1. The figures show that bilingual Hungarians in Subcarpathia choose the standard forms as grammatical less frequently than monolingual Hungarians in Hungary. Similar results were found by Lanstyák \& Szabómihály when they tested the same phenomenon among Hungarian high school students in Slovakia and in Hungary: standard forms were chosen less frequently in the former group than in the latter (1996: 116, and 1997: 31-33).

Another difference also clearly stands out if the proportions of standard vs. nonstandard answers for the two sentences are compared: in the case of the verb ending in an obstruent $+t$ (sentence 2 ), nonstandard answers were given in a much greater number of times, over half of the time, in Subcarpathia than for the verb ending in vowel+t $t$ (sentence 1). A similar tendency, although of much smaller magnitude, exists in the answers of the Hungarian control group. This finding demonstrates that the stigmatization of the merger of the indicative and imperative forms is greater in the case of verbs ending in vowel+ $t$ than in the case of those ending in obstruent $+t$, which is in accordance with the findings of the Hungarian National Sociolinguistic Survey (see Váradi \& Kontra 1995).

As a result of the heavy stigmatization of the nonstandard usage of imperative forms in place of the indicative forms, a universal tendency for hypercorrection exists among speakers of Hungarian in the entire Hungarian speech community, whereby indicative forms are used where imperative forms would be required. This hypercorrection, then, is another Universal variable. In order to see to what extent such hypercorrection exists also in Subcarpathia, subjects were asked to fill in an ending that they considered appropriate in sentence 3 and to supply the appropriate form of the verb megválaszt 'to elect' in $4:^{9}$

$\begin{array}{llllll}\text { Az-t akar-om, hogy } & \text { o nyi___ ki az ajtó-t. } & \text { ki } & \text { az } \\ \text { that-ACC want-DEF.1SG that s/he open__ PFX the door-ACC } \\ \text { 'I want him/her to open the door.' }\end{array}$

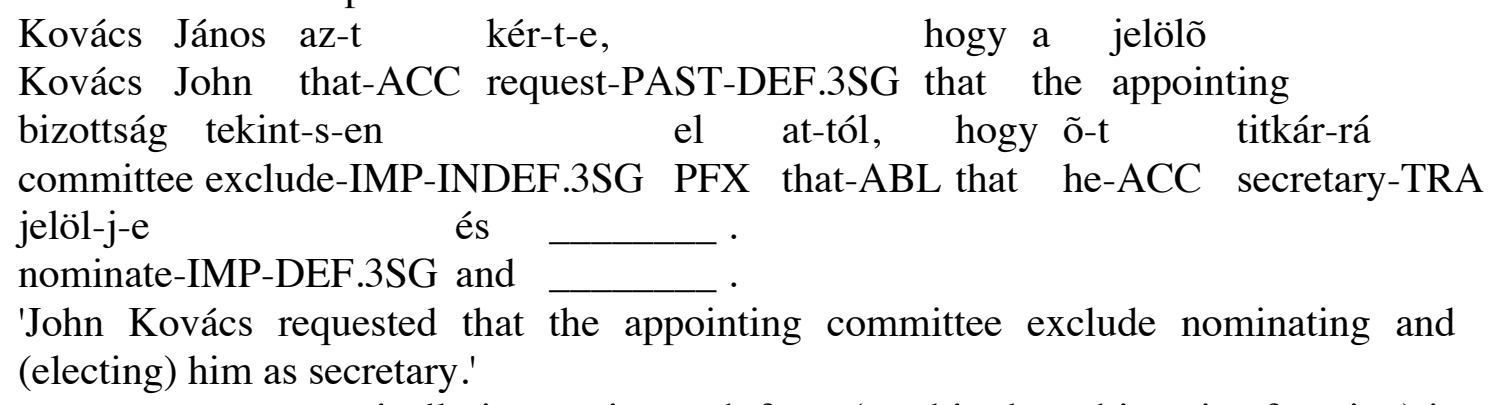

In both sentences a grammatically imperative verb form (used in the subjcuntive function) is required. The standard verb choice is nyissa (open.IMP.DEF.3SG) and megválassza (elect.IMP.DEF.3SG), whereas the hypercorrect answer is the indicative form nyitja (open.DEF.3SG) and megválasztja (elect.DEF.3SG), respectively.

As the results in Table 2 indicate, for sentence 3 the proportion of respondents choosing the hypercorrect form in Subcarpathia was virtually identical with that of respondents in Hungary. Answers for the obstruent $+t$ verb (sentence 4) were, however, somewhat different in the two places: hypercorrect forms were given more frequently in Subcarpathia than in Hungary. This demonstrates that obstruent $+t$ verbs behave differently than vowel $+t$ verbs also in respect to hypercorrection - as has also been evidenced by Lanstyák \& Szabómihály's findings among Hungarian high school students in Slovakia (1997: 34-35). 
Table 2. The choice of standard versus hypercorrect imperative forms of $t$-final verbs among speakers in Subcarpathia and in Hungary.

\begin{tabular}{||c|c|c||}
\hline & $\begin{array}{c}\text { Subcarpathia } \\
(\mathrm{N}=144)\end{array}$ & $\begin{array}{c}\text { Hungary } \\
(\mathrm{N}=107)\end{array}$ \\
\hline Sentence 3: standard (nyissa) & $96.5 \%$ & $96.3 \%$ \\
hypercorrect (nyitja) & $3.5 \%$ & $3.7 \%$ \\
\hline Sentence 4: standard (megválassza) & $86.3 \%$ & $94.4 \%$ \\
hypercorrect (megválasztja) & $13.7 \%$ & $5.6 \%$ \\
\hline \hline
\end{tabular}

Sentence 3: The Chi-square test shows the difference to not be significant

$$
\left(\chi^{2}=.013 ; p=.911\right)
$$

Sentence 4: The Chi-square test shows the difference to be significant

$$
\left(\chi^{2}=3.83306 ; \mathrm{p}=.050\right)
$$

\subsection{Compounds}

In Standard Hungarian compounds are formed through the concatenation of both derived and underived stems: vízágyú 'water cannon' is formed by combining underived stems víz 'water' and ágyú 'cannon', while vízisí 'water ski (n.)' by combining the denominal adjective vizi and the underived stem sí 'ski'. In the case of roots like viz that can appear in the nonhead position in both derived and underived forms, the root of a specific compound cannot vary freely between the derived and underived forms in different compounds, that is, for instance, vízágyú cannot be replaced by *víziágyú, or vízisí by *vízsí. Because in Slavic languages such as Russian and Ukrainian, compounding is extremely rare - these languages employ phrases involving a relational adjective and a head noun instead of compounding, e.g. Russian vodnye lyŽi (vod-n-ye lyŽ-i, water-ADER-PL ski-PL) 'water ski' - contact varieties of Hungarian in contact with Slavic languages often employ compounds with denominal adjective nonheads instead of the standard compounds whose nonhead is underived.

The items we included to test compounds of such kind are the phrases bankszámla (bank+számla) 'bank account' and légtér (lég+tér) 'air space', where the forms banki számla (bank-i számla 'bank-ADER account') and légitér (lég-i tér 'air-ADER space') are nonstandard in Hungarian usage. A Universal Contact variable, this kind of compounds was targeted with sentences 5 and 6: in 5 subjects were asked to judge the sentence (containing the nonstandard variant) and correct it if they thought it would be better in a different way, while in 6 they had to fill in what they considered to be the correct form, i.e. standard légterét or nonstandard légi terét, both meaning 'air space (ACC)':
Nem tud-om,
hogy a bank-i
számlá-já-n
mennyi 
not know-DEF.3SG that the bank-ADER account-POSS.3SG-SUP how.much pénz van.

money be.3SG

'I don't know how much money there is in his/her bank account.'

(6)

A repülõgép-ek meg-sért-ett-ék Svájc

the air.plane-PL PFX-violate-PAST-INDEF.3PL Switzerland

'The airplanes violated Switzerland's (air space).'

Table 3 shows the results for this variable: Hungarians in Subcarpathia accept the nonstandard variant to a greater extent than Hungarians in Hungary, although the difference is not statistically significant in the case of sentence 5 . The differences in the acceptance rate of the standard forms of the two items in both places as well as the relatively low percentage rate of standard answers in the case of sentence 5 stand out, however. Even though it can perhaps be due to the fact that compounds with a denominal adjectival nonhead are numerous in Hungarian and their frequency might increase subjects' willingness to accept a nonstandard compound of this kind, we believe that the reason, at least partly, lies in the task involved in sentence 5 , whose effect we discuss in subsection 5.3 below.

Table 3. The choice of a standard versus nonstandard compound among speakers in Subcarpathia and in Hungary.

\begin{tabular}{||c|c|c||}
\hline \hline & $\begin{array}{c}\text { Subcarpathia } \\
(\mathrm{N}=144)\end{array}$ & $\begin{array}{c}\text { Hungary } \\
(\mathrm{N}=107)\end{array}$ \\
\hline Sentence 5: standard (bankszámláján) & $25.9 \%$ & $35.5 \%$ \\
nonstandard (banki számláján) & $74.1 \%$ & $64.5 \%$ \\
\hline Sentence 6: standard (légterét) & $49.3 \%$ & $90.7 \%$ \\
nonstandard (légi terét) & $50.7 \%$ & $9.3 \%$ \\
\hline
\end{tabular}

Sentence 5: The Chi-square test shows the difference to not be significant

$$
\left(\chi^{2}=3.23455 ; p=.072\right)
$$

Sentence 6: The Chi-square test shows the difference to be significant

$$
\left(\chi^{2}=47.41931 ; \mathrm{p}=.001\right)
$$

\subsection{Synthetic vs. analytical constructions}

There are a number of constructions where Standard Hungarian uses highly synthetic forms where the Slavic languages which are in contact with it in Subcarpathia or Slovakia employ analytical forms. In at least one variety of Hungarian which is in contact with a Slavic language, notably Hungarian spoken in Slovakia, analytical forms replacing the standard Hungarian synthetic forms have been identified and attributed to the effect of language contact (Lanstyák \& Szabómihály 1997: 78). These constructions constitute Universal Contact variables, existing universally in the Hungarian speech community, but as the result of language contact. 
In our survey we included three variables where Standard Hungarian variants are synthetic constructions, while nonstandard variants are parallel analytical constructions whose use is either purely the result of the contact of Hungarian with Russian and Ukrainian, or intensified by such contact.

Two variables are of a kind where Standard Hungarian expresses an action with a synthetic verb form incorporating its complement by morphological means. As a result of language contact, however, such verbs are often replaced by verbs with their complements expressed as noun phrases in varieties of Hungarian which are in contact with Slavic languages. Thus, in both Slovakia and Subcarpathia the latter kind of constructions co-exist with the former. One variable we used is Standard Hungarian buszozás (busz-oz-ás, busVDER-NDER) 'traveling by bus', a nominal form of a derived denominal verb, whose nonstandard variant of the same meaning is an analytical verb phrase utazás busszal (utaz-ás busz-szal, travel-NDER bus-INS). The other variable is Standard Hungarian szépitkezik (szépít-kezik, beautify-REF) 'to beautify oneself' - a verb which is made reflexive through the derivational suffix -kezik - and whose nonstandard analytical variant is szépiti magát (szépít-i magá-t, beautify-DEF.3SG self-ACC). For the former, subjects were asked to choose, from two sentences (standard 7a or nonstandard 7b), the one which they considered better, whereas for the latter they had to fill in what they regarded as the correct form (i.e. standard szépitkezik or nonstandard szépíti magát) for sentence 8:

(7)(a) Un-om már ez-t a sok busz-oz-ás-t.

be.tired-DEF.1SG EMPH this-ACC the much bus-VDER-NDER-ACC

'I'm very tired of all this traveling by bus.'

(7)(b) Un-om már ez-t a sok utazás-t busz-szal.

be.tired-DEF.1SG EMPH this-ACC the much travel-ACC bus-INS

'I'm very tired of all this traveling by bus.'

A tükör elõtt hossz-an

the mirror in.front.of long-MOE

'She (beautified herself) in front of the mirror for a long time.'

The third variable, which we targeted with two different questions, is the Standard Hungarian inflectional suffix -hat/-het marking potential (having the ability, the opportunity, the permission, the possibility, or the right to act), whose nonstandard contact variant is the use of the auxiliary tud 'be able to', normally expressing either learned ability or potential due to circumstances. This feature is not found in Hungarian as spoken in Hungary, and is therefore a Contact (rather than a Universal Contact) variable. Bartha (1993: 138) has found this feature in the speech of Hungarian Americans in Detroit, too, and considers it the most striking kind of replacement of synthetic forms by analytical ones in contact varieties of Hungarian. The two cases for this variable were sentence 9, where subjects had to judge the sentence (which contained the nonstandard variant) and, if they thought it needed correction, to correct it, and 10, where subjects were asked to choose the sentence which they considered to be the correct one (10a with the standard form, or 10b with the nonstandard one):

(9) Ha szellõztet-ni akar-ok, így kér-ek engedély-t:

ACC

if air-INF want-INDEF.1SG this.way ask.for-INDEF.1SG permission-

ki tud-om nyit-ni az ablak-ot?

PFX be.able-DEF.1SG open-INF the window-ACC

'If I want to air the room, I ask for permission this way: 'Can I open the window?"

(10)(a) Tanító néni, fáj a fej-em. Ki-me-het-ek?

teacher aunt ache.INDEF.3SG the head-POSS.1SG PFX-go-POT-INDEF.1SG

'Miss, I have a headache. May I go out?'

(10)(b) Tanító néni, fáj a fej-em. $\quad$ Ki tud-ok 
teacher aunt ache.INDEF.3SG the head-POSS.1SG PFX be.able-INDEF.1SG men-ni?

go-INF

'Miss, I have a headache. May I go out?'

The results for the four questions are given in Table 4. As the percentages show, of the four items, the proportion of standard answers was lower in Subcarpathia than in Hungary in the case of two (sentences 8 and 10), that is, in the case of these items, in line with our expectations, Hungarians in Subcarpathia favored analytical forms to a greater extent than Hungarians in Hungary did.

Table 4. The choice of standard synthetic versus nonstandard analytical forms among speakers in Subcarpathia and in Hungary.

\begin{tabular}{||c|c|c||}
\hline \hline & $\begin{array}{c}\text { Subcarpathia } \\
(\mathrm{N}=144)\end{array}$ & $\begin{array}{c}\text { Hungary } \\
(\mathrm{N}=107)\end{array}$ \\
\hline Sentence 7: standard (buszozást) & $62.2 \%$ & $53.4 \%$ \\
nonstandard (utazást busszal) & $37.8 \%$ & $46.7 \%$ \\
\hline Sentence 8: standard (szépítkezett) & $63.2 \%$ & $80.0 \%$ \\
\hline nonstandard (szépítette magát) & $36.8 \%$ & $20.0 \%$ \\
\hline Sentence 9: standard (kinyithatom) & $85.4 \%$ & $81.3 \%$ \\
Sentence 10: standard (kimehetek) & $14.6 \%$ & $18.7 \%$ \\
\hline nonstandard (ki tudok menni) & $54.4 \%$ & $97.2 \%$ \\
\hline
\end{tabular}

Sentence 7: The Chi-square test shows the difference to be significant

$$
\left(\chi^{2}=9.58621 ; \mathrm{p}=.002\right)
$$

Sentence 8: The Chi-square test shows the difference to be significant

$$
\left(\chi^{2}=8.21083 ; \mathrm{p}=.004\right)
$$

Sentence 9: The Chi-square test shows the difference to not be significant

$$
\left(\chi^{2}=.75811 ; p=.384\right)
$$

Sentence 10: The Chi-square test shows the difference to not be significant

$$
\left(\chi^{2}=1.109 ; p=.292\right)
$$

We should also note that if we arrange by type of task the four items for synthetic vs. analytical constructions plus the item involving the underived vs. derived compound 
discussed in the previous subsection, as in Table 5, we find that questions where subjects were asked to do sentence correction, i.e. a task requiring relatively greater effort, in both Subcarpathia and Hungary more nonstandard variants were supplied than in the cases when subjects had to choose between two given alternatives in the sentence selection task and the lexical fill in the blanks task. This finding most likely indicates that the type of task bears an effect on the results for these questions.

Table 5. The effect of the task type on the results of items for compounds and synthetic vs. analytical constructions.

\begin{tabular}{||c|c|c||}
\hline & $\begin{array}{c}\text { Standard answers in } \\
\text { Subcarpathia }\end{array}$ & $\begin{array}{c}\text { Standard answers in } \\
\text { Hungary }\end{array}$ \\
\hline Sentence 6 & $25.9 \%$ & $35.5 \% \%$ \\
Task: Sentence correction - Sentence 5 & $62.2 \%$ & $53.3 \%$ \\
Sentence 8 & $63.2 \%$ & $80.0 \%$ \\
Task: Fill in the blank, lexical - Sentence 9 & $94.5 \%$ & $81.3 \%$ \\
\hline Sentence 10 & $49.3 \%$ & $97.2 \%$ \\
\hline
\end{tabular}

\subsection{The singular and plural of nouns}

In a number of cases Standard Hungarian uses singular number marking in nouns where Indo-European languages typically have plural. In nonstandard Hungarian in Hungary plural marking sometimes occurs in such cases due to the overall influence of Indo-European languages on Hungarian. Furthermore, plural agreement has been shown to occur more pronouncedly in varieties of Hungarian in situations of bilingualism where Hungarian speakers are in close contact with at least one such Indo-European language, namely, Slovak (Lanstyák \& Szabómihály 1996: 119 and 1997: 80-84). Such cases of number marking are also Universal Contact variables.

We examined number marking in two phenomena, body parts occurring in pairs and generic reference to a class of things, for both of which Standard Hungarian employs singular. Body parts occurring in pairs (e.g. eyes, ears, hands, arms, feet, legs, etc.) and pieces of clothing belonging to such body parts (e.g. trousers, shorts, shoes, etc.) are referred to in the singular and receive singular subject-verb agreement. In reference to a group of identical items, too, the singular is used in Standard Hungarian. In nonstandard usage, the plural is used in both of these cases. In sentence 11a subjects had to fill in missing endings for number marking on body parts and person/number marking on verbs agreeing with the body parts: 
(11)(a) Erzsi néni-nek fáj___ a szív__, Kati néni-nek meg a

Liz aunt-DAT ache__ the heart_ Kathy aunt-DAT and the

láb-a__ is fáj_

foot-POSS.3SG_ also ache

'Aunt Liz has a pain in her heart [lit. her heart aches] and Aunt Kathy has aching feet

[lit. her feet ache].'

In Standard Hungarian the fitting answers are as in $11 \mathrm{~b}$ and $11 \mathrm{c}$, whereas the nonstandard variant of the second phrase is as in 11d (as the first phrase involves the heart, a non-paired body part, it therefore does not have a nonstandard variant):

(11) Standard:

(b) fáj a szív-e

ache.INDEF3SG the heart-POSS.3SG

'her heart aches'

(c) a láb-a is fáj

the foot-POSS.3SG also ache.INDEF.3SG

'her feet ache, too'

(11)(d) Nonstandard: a láb-a-i is fáj-nak

the foot-POSS.3SG-POSS.PL also ache-INDEF3PL

'her feet ache, too'

For the second variable, subjects had to choose which sentence they considered as more correct, sentence $12 \mathrm{a}$, the standard variant with singular number marking, or sentence $12 \mathrm{~b}$, the one with nonstandard plural marking:

(12)(a) Néz-d, milyen szép banán-t árul-nak az üzlet-ben!

look-IMP.2SG what beautiful banana-ACC sell-INDEF.3PL the store-INE

'Look, what beautiful bananas are being sold in the store!'

(12)(b) Néz-d, milyen szép banán-ok-at árul-nak az üzlet-ben!

look-IMP.2SG what beautiful banana-PL-ACC sell-INDEF.3PL the store-INE

'Look, what beautiful bananas are being sold in the store!'

Table 6 summarizes the results for these two variables: the proportion of standard answers is higher in Hungary for both. These results agree with similar findings that were reported about number marking in the speech of Hungarian high school students in Slovakia and Hungary (Lanstyák \& Szabómihály 1996: 119, and 1997: 81).

Table 6 . The choice of standard versus nonstandard number marking among speakers in Subcarpathia and in Hungary.

\begin{tabular}{||c|c|c||}
\hline \hline & $\begin{array}{c}\text { Subcarpathia } \\
(\mathrm{N}=144)\end{array}$ & $\begin{array}{c}\text { Hungary } \\
(\mathrm{N}=107)\end{array}$ \\
\hline nonstandard (fájnak a lábai) & $67.8 \%$ & $94.9 \%$ \\
Sentence 11: standard (fáj a lába) & $32.2 \%$ & $8.1 \%$ \\
\hline nentence 12: standard (banánt) & $62.9 \%$ & $12.1 \%$ \\
\hline
\end{tabular}

Sentence 11: The Chi-square test shows the difference to be significant 


$$
\left(\chi^{2}=25.53270 ; p=.001\right)
$$

Sentence 12: The Chi-square test shows the difference to be significant

$$
\left(\chi^{2}=19.55079 ; p=.001\right)
$$

\subsection{Agreement features}

In a small number of cases, Standard Hungarian uses singular number agreement where most Indo-European languages (and, under their overall influence, nonstandard Hungarian usage in Hungary) employ the plural. We hypothesized that, just like in number marking, in these cases (which, again, constitute Universal Contact features) the use of the nonstandard Slavic-like variants is more widespread in varieties of Hungarian in closer contact with Slavic languages.

In cases where plural subjects are related to one thing of the same kind each (e.g. as in 'The boys sit on chairs', where for every boy there is one chair), the noun expressing the thing to which the subjects are related appears in the singular in Standard Hungarian. This phenomenon was tested in sentence 13, where subjects had to fill in either the standard autóban (autó-ban, car-INE) 'in the car', or the nonstandard autókban (autó-k-ban, car-PLINE) 'in cars', depending on which they thought fit the sentence better (both variants were given after the sentence):

$$
\begin{array}{cccc}
\text { Az autó-s } & \text { mozi-ban az utas-ok } & \text { ül-ve } \\
\text { the car-ADER } & \text { movies-INE the passenger-PL } & \text { sit-APRT } \\
\text { néz-het-ik } & \text { a film-et. } &
\end{array}
$$

watch-POT-DEF.3PL the movie-ACC

'In drive-in movies the passengers watch the movie sitting in their cars.'

In Standard Hungarian agreement is also singular on adjectival phrases when plural subjects or objects have adjectival complements governed by verbs. In such cases Slavic languages like Russian and Ukrainian employ plural agreement. This phenomenon was included in two sentences, 14 (with a subject complement) and 15 (with an object complement): in 14 subjects had to select one of the two sentences, standard (a) or nonstandard (b), whichever they considered better, while in 15 they had to fill in one of the two supplied phrases in the sentence, standard komolynak (komoly-nak, serious-DAT) or nonstandard komolyaknak (komoly-ak-nak, serious-PL-DAT).

(14)(a) A mai gyerek-ek at-tól vál-nak önzõ-vé, hogy the today child-PL that-ABL become-INDEF.3PL selfish-TRA that minden-t meg-kap-nak. everything-ACC PFX-get-INDEF.3PL

'Modern children become selfish because they get everything [that they want].'

(14)(b) A mai gyerek-ek at-tól vál-nak önzõ-k-ké, hogy the today child-PL that-ABL become-INDEF.3PL selfish-PL-TRA that minden-t meg-kap-nak. everything-ACC PFX-get-INDEF.3PL 'Modern children become selfish because they get everything [that they want].' A képviselõ-k az ok-ok-at the representative-PL the reason-PL-ACC tart-ott-ák.

'The representatives considered the reasons (serious).' consider-PAST-DEF.3PL

The proportions of standard singular agreement are higher in Hungary than in Subcarpathia in the case of all three sentences (see Table 7).

Table 7. The choice of standard versus nonstandard agreement marking among speakers in Subcarpathia and in Hungary. 


\begin{tabular}{||c|c|c||}
\hline \hline & $\begin{array}{c}\text { Subcarpathia } \\
(\mathrm{N}=144)\end{array}$ & $\begin{array}{c}\text { Hungary } \\
(\mathrm{N}=107)\end{array}$ \\
\hline Sentence 13: standard (autóban) & $59.4 \%$ & $86.9 \%$ \\
\hline nonstandard (autókban) & $40.6 \%$ & $13.1 \%$ \\
\hline nontence 14: standard (önzövé) & $40.3 \%$ & $70.1 \%$ \\
Sentence 15: standard (komolynak) & $59.7 \%$ & $29.9 \%$ \\
\hline nonstandard (komolyaknak) & $45.8 \%$ & $70.1 \%$ \\
\hline
\end{tabular}

Sentence 13: The Chi-square test shows the difference to be significant $\left(\chi^{2}=22.53166 ; p=.001\right)$

Sentence 14: The Chi-square test shows the difference to be significant $\left(\chi^{2}=21.90664 ; p=.001\right)$

Sentence 15: The Chi-square test shows the difference to be significant $\left(\chi^{2}=14.67554 ; p=.001\right)$

\subsection{Feminine forms of profession nouns}

Hungarian does not mark grammatical gender anywhere in its grammatical system, and nouns denoting professions do not express gender through derivation as they do in Russian or Ukrainian (cf. Russian doktor '(male) doctor' vs. doktor ̌̌a 'female doctor'). It is only rarely possible in Hungarian to indicate that a person in a profession is female: compounded forms involving a profession designation followed by the head no 'woman' are used in the case of professions either typically (or sometimes exclusively) occupied by females (e.g. varrónõ 'dressmaker', védõñ 'district nurse', or apácafõnöknõ 'mother superior') or when the noncompounded form refers specifically to a male (cf. király 'king' vs. királynõ 'queen', színész 'actor' vs. színésznõ 'actress', or szakács 'chef, cook' vs. szakácsnõ 'female cook'). The number of compounded female profession nouns used on a regular basis is rather limited, Papp (1969) lists only slightly more than 60. In the case of the rest of all profession nouns, whenever it is clear from the context that the person referred to is a female, the noncompounded profession noun is used, and a compounded form is only used to make unambiguous reference to a female when no clues are available from the context.

Varieties of Hungarian in contact with Slavic languages - namely, with Slovak have been previously shown to employ compounded feminine profession nouns even when not necessitated by the context (Lanstyák \& Szabómihály 1996: 122-123).

In our survey we used three sentences to examine the use of such profession nouns. Sentences 16 and 17 were given as continuous text, while 18 was included under a separate item number, and subjects had to fill in one of two variants provided after each sentence, depending on which one they thought would fit the sentence better. The choices were standard tanár 'teacher' and nonstandard tanárnõ 'female teacher' for 16, standard igazgató 
'headmaster' and nonstandard igazgatónõ 'headmistress' for 17, and standard fodrász 'hairdresser' and nonstandard fodrásznõ 'female hairdresser' for 18.
(16) Anyá-m
egy középiskolá-ban tanít,
o tehát
mother-POSS.1SG a high.school-INE teach.INDEF.3SG she so

'My mother teaches in a highschool, so she is (a teacher).

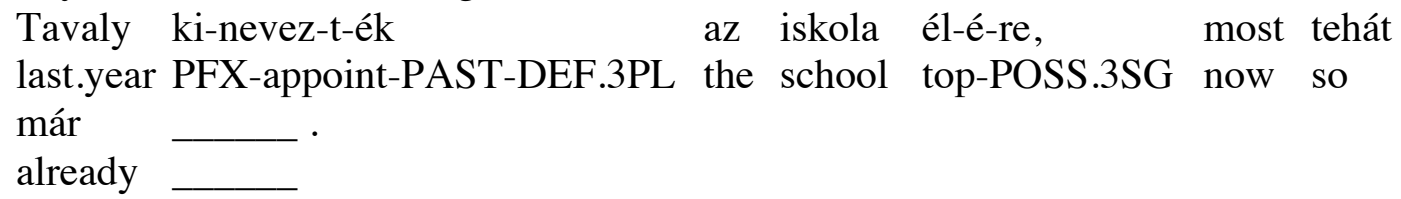

'I have known Julie Kovács for a long time. Ever since we moved here I have been having her do my hair, that is, she is (my hairdresser).'

As Table 8 demonstrates, in the case of all three items, the proportion of standard answers was higher in Hungary than in Subcarpathia. The number of standard answers, however, is clearly lower in the case of sentence 16 than in the other two sentences for both groups of subjects. This is most likely due to the fact that the form tanárnõ 'female teacher' is used as a form of address towards female teachers - it is, indeed, by far the most common address form for a teacher used universally by both students and their parents, and can be used by nonteaching school staff as well. Even though igazgatónõ 'headmistress' can also be used as a form of address, it is much less common due to the fact that females occupy the post of headmasters traditionally much rarer than males. The form fodrásznõ 'female hairdresser', however, cannot be used as a form of address. We are indebted for this explanation to Lanstyák \& Szabómihály (1997: 73).

Table 8 . The choice of standard versus nonstandard profession nouns among speakers in Subcarpathia and in Hungary.

\begin{tabular}{||c|c|c||}
\hline \hline & $\begin{array}{c}\text { Subcarpathia } \\
(\mathrm{N}=144)\end{array}$ & $\begin{array}{c}\text { Hungary } \\
(\mathrm{N}=107)\end{array}$ \\
\hline Sentence 16: standard (tanár) & $31.3 \%$ & $58.7 \%$ \\
nonstandard (tanárnó) & $68.8 \%$ & $41.3 \%$ \\
\hline nentence 17: standard (igazgató) & $77.6 \%$ & $82.5 \%$ \\
\hline Sentence 18: standard (fodrászom) & $22.4 \%$ & $17.5 \%$ \\
\hline
\end{tabular}




\begin{tabular}{|c|c|c||}
\hline nonstandard (fodrásznőm) & $27.3 \%$ & $10.5 \%$ \\
\hline
\end{tabular}

Sentence 16: The Chi-square test shows the difference to be significant $\left(\chi^{2}=19.15658 ; p=.001\right)$

Sentence 17: The Chi-square test shows the difference to not be significant $\left(\chi^{2}=.94080 ; \mathrm{p}=.332\right)$

Sentence 18: The Chi-square test shows the difference to be significant $\left(\chi^{2}=10.61161 ; p=.001\right)$

\subsection{Calques}

Hungarians in Subcarpathia use calques from Russian and Ukrainian in their Hungarian often. We examined their acceptance of calqued forms in a test situation with two variables, kiirrat (ki-írat, out-write.CAU) 'subscribe', and becsenget (be-csenget, in-ring) 'telephone', calqued on Russian vypisat' (vy-pisat', out-write) and pozvonit' (po-zvonit', PFXring), respectively. The standard Hungarian forms for the two verbs are eloffizet (elõ-fizet, pre-pay) 'subscribe' and telefonál 'telephone'. Both calques are widely used in Subcarpathia and have been stigmatized by local prescriptivists in recent years (cf. Horváth 1991, or Kótyuk 1995: 63-64). Both are forms that can clearly be considered contact features of Hungarian in Subcarpathia that do not exist in Hungary with the above meanings. The two verbs have different meanings in Standard Hungarian: kiirat means 'get oneself certified as sick (by doctor)', while becsenget means 'ring doorbell'.

The two calqued verbs were included in sentences 19 and 20, respectively, where subjects had to judge the two sentences and to correct them if they thought they needed to be corrected.

(19) Péter er-re az év-re is ki-ír-at-t-a a Kárpáti

Peter this-SUB the year-SUB also out-write-CAU-PAST-DEF.3SG the Kárpáti

Igaz Szó-t.

Igaz Szó-ACC

'Peter subscribed to Kárpáti Igaz Szó for this year as well.'

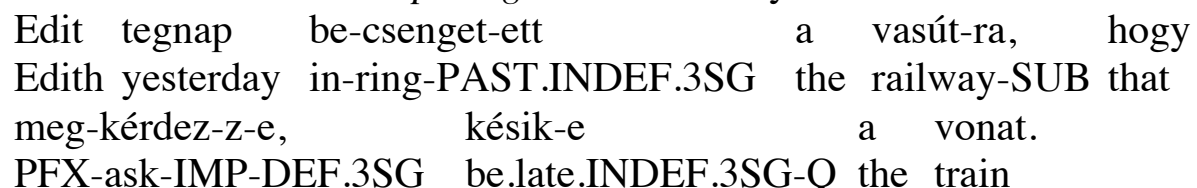

'Yesterday Edith called the railway station to ask whether the train was late.'

The standard variant for the verbs in question is eloffizette 's/he subscribed' and telefonált 's/he telephoned'.

The results for the two sentences are summarized in Table 9. It is not surprising that Subcarpathian subjects had a high acceptance rate for the nonstandard calqued forms - after all, they have parallels in another language of this multilingual population. We find the relatively high acceptance rates of the nonstandard variants by subjects in Hungary rather unexpected, however. The reason for such relatively high acceptance can perhaps lie in a combination of three factors. First, calques may be less discernible to monolingual Hungarians than loanwords. Second, the use of calques is less stigmatized as foreign and therefore incorrect and undesirable by prescriptivist language cultivators in Hungary, who have been publicly expressing their anti-loanword views amidst an influx of loanwords in recent years. The third possible factor lies in the design of the survey: sentences 19 and 20 involved the sentence correction task, which, as we have shown in connection with sentences 6 and 7 above, may have an effect on subjects' answers. 
The clearly high acceptance of the nonstandard calqued forms by the Subcarpathian subjects, however, we believe, requires an explanation beyond the effect of the type of task, which, as we have seen, may foster an acceptance of nonstandard forms. These calques, together with several others, constitute a part of what is best regarded as a Subcarpathian Standard Hungarian variety: a variety which, as has been argued for by Beregszászi (1997) and Csernicskó (1997c), displays the characteristics of a standard variety and should, therefore, be acknowledged as such and included in dictionaries that play a significant role in codifying Standard Hungarian such as the Concise Defining Dictionary of Hungarian. This, in turn, would support the view, proposed by Lanstyák (1995a, 1995b) and Lanstyák \& Szabómihály (1997) and shared by us, too, that Hungarian is a pluricentric language and should be regarded as such, with all the linguistic and sociolinguistic consequences that this entails. (For a discussion of how the idea of pluricentiricity of Hungarian was received by conservative linguists in Hungary, see Kontra 1997.)

Table 9. The choice of standard vs. nonstandard calqued verbs among speakers in Subcarpathia and in Hungary.

\begin{tabular}{|c|c|c||}
\hline & $\begin{array}{c}\text { Subcarpathia } \\
(\mathrm{N}=144)\end{array}$ & $\begin{array}{c}\text { Hungary } \\
(\mathrm{N}=107)\end{array}$ \\
\hline Sentence 19: standard (elöfizette) & $17.4 \%$ & $66.0 \%$ \\
nonstandard calque (kiíratta) & $82.6 \%$ & $34.0 \%$ \\
Sentence 20: standard (telefonált) & $29.2 \%$ & $56.7 \%$ \\
nonstandard calque (becsengetett) & $70.8 \%$ & $43.3 \%$ \\
\hline
\end{tabular}

Sentence 19: The Chi-square test shows the difference to be significant $\left(\chi^{2}=55.58110 ; p=.001\right)$

Sentence 20: The Chi-square test shows the difference to be significant $\left(\chi^{2}=21.62264 ; p=.001\right)$

\section{SOCIAL STRATIFICATION}

In our study we used the following social variables: sex ( 2 groups), age ( 3 groups: young, middle aged, and elderly), education (2 groups: elementary school educated and college educated), and settlement type. For the latter variable we used 4 groups in Subcarpathia along the village vs. town, and minority vs. majority Hungarian population oppositions. For the Hungary control group we used one settlement type, villages, due to the monolingual Hungarian data available. For more details of the social variables and criteria, see section 3 above.

\subsection{SEX}


Sex showed a statistically significant correlation with linguistic variables in 3 cases (variables 14, 15, and 18) ${ }^{10}$ in Subcarpathia, and in 6 cases (variables 8-11, 14, and 15) in Hungary. In all cases, women had higher rates for standard variants than men, as has been the case in all sociolinguistic studies everywhere where gender has been found to be a significant factor of variation in the use of standard forms (Chambers 1995: 102-145).

\subsection{AGE}

In 3 cases each in the Subcarpathian sample and the sample from Hungary age was statistically significant. In each of the 3 linguistic variables in question (variables 12, 16, and 17), the subjects from Hungary who had the highest rate for standard forms were the oldest group, those over 60, and in 2 of these 3 cases the youngest group (18-27-year-olds) had the lowest rates for standard forms. (The correlation was significant at the $\mathrm{p}<.05$ level for variables 12 and 16 , and at the $\mathrm{p}<.01$ level for variable 17.)

The results were more varied in the case of Subcarpathians. For variable 7, at the $\mathrm{p}<.01$ level, the highest rate of standard answers was given by the youngest group, a lower rate by the middle aged group (32-52-year-olds), and the lowest by the oldest group. In the case of variable 13, at the $\mathrm{p}<.05$ level, however, the youngest group was the least standard, and the oldest the most standard. In the case of the third variable, sentence 19, the highest rate of standard answers was supplied by the middle aged group, a lower rate by the youngest group, and the lowest by the oldest group, at the $\mathrm{p}<.05$ level for age.

Thus we can see that the results are mixed for age as an independent variable. We believe that we do not have enough evidence to propose an explanation of this rather mixed picture. We can, however, safely conclude that our results demonstrate that the widely held but empirically hithertofore unsupported belief that the speech of the oldest generation is least affected by the linguistic results of language contact while that of the youngest displays the most interference (cf. for instance Horváth 1998) cannot be maintained.

\subsection{EDUCATION}

The results where the level of education is a statistically significant factor can only be taken with some caution due to the fact that the educational systems of Ukraine and Hungary have crucial differences. The main difference is that in Hungary elementary education has traditionally been 8 years followed by 4 years of secondary education, while Ukraine, similarly to the rest of the former Soviet Union, has had 10-year schools comprising in one and the same school type the 8 years of elementary and the two years of secondary education. (College education is similarly 4 or 5 years in both countries.) Because completion of secondary education would thus mean 12 years or education in Hungary and only 10 in Subcarpathia, we used only the two education levels that are more comparable to each other in the two countries, namely elementary vs. college education.

Level of education played a statistically significant role in the results for 14 linguistic variables in Subcarpathia, and for 6 in Hungary. The linguistic variables in question were variables 1, 2, 5-14, 19 and 20 in the former case, and variables 2, 4, 6, 12, 13, and 19 in the latter. In the case of all linguistic variables, in both places, college education correlated in a statistically significant way with standard forms (at a $\mathrm{p}<.01$ level for all variables except for variables 2 and 19 and at a $p<.05$ level for the latter two in Subcarpathia, and at a $p<.01$ level for variables 6 and 19 and a $p<.05$ level for the rest in Hungary).

\subsection{SETTLEMENT TYPE}

Settlement type was included as a variable only in the case of the Subcarpathian sample, not in the Hungary sample. In treating settlement type in Subcarpathia we used two two-way distinctions: town (UŽhorod/Ungvár and Berehove/Beregszász) vs. village 
(Esen'/Eszeny, Rakošino/Beregrákos and Kholmok/Kincseshomok), and Hungarian population in majority (Berehove/Beregszász and Esen'/Eszeny) vs. minority (UŽhorod/Ungvár, Rakošino/Beregrákos and Kholmok/Kincseshomok). For more details about the settlements in question, see section 3 above.

The town vs. village distinction was statistically significant in the case of 9 linguistic variables, variables $2,6,10-15$, and 20 , for 6 variables $(6$, and 10-14) at a $\mathrm{p}<.01$ level, and 3 variables $(2,15$, and 20$)$ at a $p<.05$ level. In the case of all of these linguistic variables, residence in a town correlated with standard answers.

The majority vs. minority status of Hungarians in a place showed statistical significance in the case of 8 variables $(4,6,8$, and 11-15), in all cases at a $p<.01$ level, and, not surprisingly, in all cases residence in a place with a Hungarian population in the majority correlated with standard answers.

\section{DISCUSSION}

\subsection{HYPOTHESIS A: ACCEPTANCE OF STANDARD VS. NONSTANDARD FORMS}

In 13 of the 16 variables that we examined, the rate of standard answers was higher in Hungary than in Subcarpathia, and only in 3 (variables 3, 7, and 9) was the reverse true. This confirms our Hypothesis A. It also supports the widely accepted view that the varieties of Hungarian used in minority settings are characterized more by the use of dialectal and regional features and are less standard than the Hungarian spoken in Hungary (cf. Deme 1970: 39, Lanstyák 1994: 64, Sándor 1995: 132-133, or, specifically on the Hungarian spoken in Subcarpathia, Horváth 1991, and Kótyuk 1995: 7). To date, this view has been supported empirically only in the case of the variety of Hungarian spoken in Slovakia (Szabómihály 1993, and Lanstyák \& Szabómihály 1996 and 1997).

\subsection{HYPOTHESIS B: U VS. UC VS. C VARIABLES}

The three kinds of linguistic variables - the Universal, Universal Contact, and Contact variables - that we identified and used were judged differently, confirming our Hypothesis B. The three kinds of variables, then, cannot be treated uniformly in the future after all, their acceptance by members of a speech community is not uniform either. Our expectation that the monolingual control group from Hungary would firmly reject and stigmatize nonstandard variants of Contact variables was not fulfilled (see our discussion of variables 18 and 19 in subsection 5.7 above).

\subsection{SOCIAL STRATIFICATION}

As discussed in section 6, we have identified statistically significant correlations between linguistic and social variables, thereby demonstrating that a social stratification exists in the use of Hungarian in Subcarpathia and confirming our Hypothesis C. Our results demonstrate that education and type of settlement are especially important social variables determining Hungarian language use in Subcarpathia, while sex and, surprisingly for us, age play a more minor role. An important finding for sociolinguistic research on monolingual Hungarians is that age plays a lesser role than sex and education in Hungary as well.

\section{CONCLUSION}

In this study we have demonstrated that statistically significant differences in Hungarian language use exist between monolingual speakers in Hungary and bilingual (or multilingual) speakers in Subcarpathia, thereby showing that the Hungarian community of Subcarpathia cannot be treated as sociolinguistically homogeneous and disproving traditional views to the contrary: whatever scarce literature on the bilingualism and Hungarian language 
use in Subcarpathia that has existed so far has regarded this Hungarian community as unified in its language use, giving rise to the false notion that bilingualism has the exact same type of effect on virtually every member of the community and uniformly to the exact same extent (see, for instance, Rot 1967 and Kótyuk 1995) (a similar phenomenon has been noted in connection with other bilingual communities by Fishman (1968: 29-30)). Further research will, of course, be needed to describe Hungarian language use and bilingualism in Subcarpathia in more depth and detail, but the position that Subcarpathia is sociolinguistically heterogeneous is strongly supported. 
Notes:

1 We would like to thank Miklós Kontra and Don Peckham for their comments on earlier versions of this paper. Thanks are also due to Anikó Beregszászi, who, together with István Csernicskó, administered the questionnaire for this project in Subcarpathia. This work was supported by the Research Support Scheme of the Higher Education Support Programme, grant number 582/1995.

${ }^{2}$ P. N. Lizanec uses various Latin transliterations of his own name in different publications. We use the spelling of his name as it appears in each given publication.

${ }^{3}$ For a discussion of the reason for including only these two levels of education, see section 6.3 below.

${ }^{4}$ The definition of places with a "minority population of Hungarians" used in the larger research project was towns or villages with a less than $30 \%$ minority population of Hungarians. However, for Subcarpathia, this cut-off point had to be raised to $45 \%$ in the case of villages, because in the four administrative districts along the Hungarian-Ukrainian border we only found villages either with a proportion of Hungarian population that we considered too small for our purposes, or with a minority population that amounted to more than $30 \%$ of the total.

${ }^{5}$ Because census data concerning minorities in the various settlements in the former Soviet Union is only partially available to the general public, we were not able to find information on what proportion of Hungarians in Subcarpathia live in each of our four settlement types in order to stratify our sample by settlement type accordingly. Therefore, we used an approximately equal number of subjects from each of the four settlement types. We were, however, able to find 1989 census data on what the proportion of Hungarians is in individual places: in nine of the ten Subcarpathian towns ethnic Hungarians constituted a minority, and only in one, Berehove/Beregszász a majority; in eight towns - in UÏhorod/Ungvár among them - the proportion of Hungarian residents was under 30\% (cf. Csernicskó 1997b). 
${ }^{6}$ We want to thank leader of the research project Miklós Kontra for making his data on the monolingual Hungarian control group available to us.

7 In Hungarian, all finite verbs are inflected for either the indefinite or the definite conjugations: the verb is indefinite if it is intransitive, or if it is transitive and governs an indefinite object (typically, an object noun phrase with an indefinite article); and the verb is definite if it is transitive and governs a definite object, usually a proper noun or a noun phrase with a definite article. (For more details on the definite vs. indefinite conjugations, see Fenyvesi 1998:321-327.)

8 Throughout this paper, hyphens indicate morpheme boundaries in example sentences. Orthographically, no hyphens would be used in any of the sentences. In the morpheme-bymorpheme glosses of the Hungarian sentences we use the following abbreviations:
$1 \mathrm{SG}$ - first person singular
INDEF - indefinite conjugation
2SG - second person singular
INE - inessive case
3SG - third person singular
INS - instrumental case
1PL - first person plural
MOE - modal-essive case
$3 \mathrm{PL}$ - third person plural
NDER - suffix deriving a noun
ABL - ablative case
PAST - past tense
ACC - accusative case
PFX - verbal prefix
$\mathrm{ADE}$ - adessive case
PL - plural
ADER - suffix deriving an adjective
POSS - possessive personal ending
APRT - active (present) participle
POT - potential suffix
CAU - causative derivational suffix
$\mathrm{Q}$ - question particle
DAT - dative case
REF - reflexive derivational suffix
DEF - definite conjugation
SUB - sublative case
EMPH - emphasis marker
SUP - superessive case
ESS - essive case
TRA - translative case
IMP - imperative
VDER - suffix deriving a verb. 
${ }^{9}$ Whenever the task involved required subjects to fill in a complete word, this word is indicated by a blank in the Hungarian sentences and the line containing the morpheme-bymorpheme glosses, and by the appropriate word supplied in brackets in the English translation, as in sentence 4 , for instance.

${ }^{10}$ For brevity's sake, in this section we refer to the linguistic variables discussed in section 5 by the numbers of the sentences they occur in - the reader should refer back to this section for linguistic details. 


\section{REFERENCES:}

Auer, Peter and Frans Hiskens

1996 The convergence and divergence of dialects in Europe: New and not so new developments in an old area. In Ammon, Ulrich, Klaus J. Mattheier, and Peter H. Nelde (eds.) Sociolinguistica, International Yearbook of European Sociolinguistics, Volume 10: Convergence and divergence of dialects in Europe. Tübingen: Max Niemeyer, 1-30.

Bartha, Csilla

1993 Egy amerikai magyar közösség nyelvhasználatának szociolingvisztikai megközelitései [Sociolinguistic approaches to the language use of a Hungarian American community]. Budapest: Kandidátusi dissertation.

Balogh, Lajos

1991 A suksükölés [The indicative use of the imperative of $t$-final verbs]. Kárpáti Igaz Szó, November 12, 1991, p. 3.

Beregszászi, Anikó

1995/1996 Language planning issues of Hungarian place-names in Subcarpathia. Acta Linguistica Hungarica 43(3-4), 373-380.

1997 Kárpátaljai szavak a Magyar Értelmezõ Kéziszótárban? [Subcarpathian words in the Concise Defining Dictionary of Hungarian?] Pánsíp 5(2), 24-27.

Botlik, József and György Dupka

1993 Magyarlakta települések ezredéve Kárpátalján [A thousand years of the Hungarian populated settlements in Subcarpathia]. UŽhorod and Budapest: Intermix Kiadó.

Chambers, J. K.

1995 Sociolinguistic theory: Linguistic variation and its social significance. Oxford: Blackwell.

Csernicskó, István

1997a A kárpátaljai magyarok kétnyelvûsége [The bilingualism of the Hungarians in Subcarpathia]. Szivárvány 18(2), 117-124.

1997b A számok tükrében: Kárpátalja lakosságának nemzetiségi megoszlása a legutóbbi szovjet népszámlálás (1989) adatai alapján, némi kitekintéssel [As mirrored in the numbers: Some comments on the nationality figures of the population of Subcarpathia as reported in the latest Soviet census of 1989]. Forrás 1997(2), 7076.

1997c Kárpátaljai szójegyzék [A list of Subcarpathian vocabulary]. Pánsíp 5(2), 28-29.

Deme, László

1970 Nyelvi és nyelvhasználati gondjainkról [On our problems with language and language use]. Bratislava: Madách.

Fenyvesi, Anna

1995 Hungarian diglossia in Slovakia: A new linguistic approach. Budapest Review of BOOKS 1995(2), 37-39.

1998 Inflectional morphology. In Kenesei, István, Robert M. Vago, and Anna Fenyvesi. Hungarian. (Descriptive Grammars Series). London and New York: Routledge, 191-351.

Fishman, Joshua A.

1968 Sociolinguistic perspective on the study of bilingualism. Linguistics 39, 21-49.

Goebl, Hans, Peter H. Nelde, Zdene4k Stary4 and Wolfgang Wölck (eds.)

1997 Contact linguistics: An international handbook of contemporary research, Volume 2. Berlin \& New York: Walter de Gruyter. 
Grétsy, László and Miklós Kovalovszky (eds.)

1983 Nyelvmûvelõ kézikönyv, I [Language cultivation handbook, Volume 1]. Budapest: Akadémiai Kiadó.

Györke, Magdolna

1991 A kárpátaljai magyar szaknyelvek [Subcarpathian Hungarian registers]. In GyõriNagy, Sándor and Janka Kelemen (eds.) Kétnyelvûség a Kárpát-medencében I [Bilingualism in the Carpathian Basin, Volume I]. Budapest: Széchenyi Társaság \& Pszicholingva Nyelviskola, 70-71.

Horváth, Katalin

1976 A kárpátontúli magyar nyelvjárások magánhangzórendszere [The vowel systems of the Hungarian regional dialects beyond the Carpathian Mountains]. UŽhorod: Ungvári Állami Egyetem.

1991 Szebben beszélünk, mint Magyarországon? [Do we speak a more beautiful Hungarian than people in Hungary?] Kárpáti Igaz Szó, November 13, 1991, p. 8.

1998 Újabb keletû szláv átvételeink [Our recent Eastern Slavic loanwords]. Kárpáti Igaz Szó, February 14, 1998, p. 13.

Kontra, Miklós

1995a Sociopolitical and linguistic aspects of post-communist Hungarian contact linguistics. In Muikku-Werner, P. and K. Julkunen (eds.) Kielten väliset kontaktit. AFinLAn vuosikirja 1995. Suomen soveltavan kieltieteen yhdisteyken (AFinLA) julkaisuja no. 53. Jyväskylä: AFinLa, 7-23.

$1995 \mathrm{~b}$ Does the educational level of speakers matter in Hungarian language use? In Viereck, Wolfgang (ed.) Proceedings of the International Congress of Dialectologists. Bamberg, 29.7. - 4.8. 1990. Vol. 4 Zeitschrift für Dialektologie und Linguistik, Beiheft 77. Stuttgart, 61-69.

1997 Hungarian linguistic traitors champion the cause of contact dialects. In Wölck, Wolfgang and A. de Houwer (eds.) Recent studies in contact linguistics. Bonn: Dümmler, 181-187.

1998 Final report to the Research Support Scheme on 'The sociolinguistics of Hungarian outside Hungary'. Budapest: Linguistics Institute, Hungarian Academy of Sciences MS.

Kótyuk, István

1995 Anyanyelvünk peremén [On the outskirts of our mother tongue]. UŽhorod \& Budapest: Intermix Kiadó.

Lanstyák, István

1994 Kétnyelvûség és nemzeti nyelv [Bilingualism and national language]. Irodalmi Szemle 37(2), 63-75.

1995a A magyar nyelv központjai [The centers of the Hungarian language]. Magyar Tudomány, 40(10), 1170-1185.

1995b Többközpontú nyelv-e a magyar? [Is Hungarian a pluricentric language?]. Irodalmi Szemle 38(1), 72-84.

Lanstyák, István and Gizella Szabómihály

1996 Contact varieties of Hungarian in Slovakia: A contribution to their description. International Journal of the Sociology of Language 120, 111-130.

1997 Magyar nyelvhasználat - iskola - kétnyelvûség [Hungarian language use, schools, and bilingualism]. Bratislava: Kalligram Könyvkiadó.

Lizanec, P. N.

1992 A kárpátaljai magyar nyelvjárások atlasza, I. kötet [Atlas of Hungarian dialects in Subcarpathia, Volume 1]. Budapest: Akadémiai Kiadó. 
1996 A kárpátaljai magyar nyelvjárások atlasza, II. kötet [Atlas of Hungarian dialects in Subcarpathia, Volume 2]. UŽhorod: Patent Nyomdaipari Vállalat.

Lizanyec P. N. and Katalin I. Horváth

1981 A kárpátontúli magyar nyelvjárások fõbb sajátosságairól [On the most important characteristics of regional dialects of Hungarian beyond the Carpathian Mountains]. Magyar Nyelvjárások 34, 3-18.

Magocsi, Paul Robert

1996 The Hungarians in Transcarpathia (Subcarpathian Rus'). Nationalities Papers 24(3):525-534.

Milroy, Lesley

1980 Language and social networks. Oxford: Blackwell.

Papp, Ferenc

1969 Reverse-alphabetized dictionary of the Hungarian language. Budapest: Akadémiai Kiadó.

Poplack, Shana

1993 Variation theory and language contact: concepts, methods and data. In Preston, Dennis R. (ed.) American Dialect Research. Amsterdam: John Benjamins, 251286.

Rot, Sándor

1967 Magyar-ukrán és ukrán-magyar kétnyelvûség Kárpát-Ukrajnában [HungarianUkrainian and Ukrainian-Hungarian bilingualism in Subcarpathian Ukraine]. Magyar Nyelvõr 91, 185-191.

Sándor, Klára

1995 Az élõnyelvi vizsgálatok és az iskola: A kisebbségi kétnyelvûség [Sociolinguistic research and school: Minority bilingualism]. Regio 4(4), 121-148.

Shamshur, Oleg V. and Tetiana I. Izhevskaya

1993 Multilingual education as a factor of inter-ethnic relations: The case of the Ukraine. In Ager, D., G. Muskens, and S. Wright, eds. Language education for intercultural communication. Clevedon, Philadelphia \& Adelaide: Multilingual Matters, 159-167.

Szabómihály, Gizella

1993 Nyelvhasználat és szociális háttér [Language use and social background]. Hungarológia 3, 59-72.

Váradi, Tamás and Miklós Kontra

1995 Degrees of stigmatization: $t$-final verbs in Hungarian. In Viereck, Wolfgang (ed.) Proceedings of the International Congress of Dialectologists. Bamberg, 29.7. 4.8. 1990. Vol. 4 Zeitschrift für Dialektologie und Linguistik, Beiheft 77. Stuttgart, 132-142.

Vargha, András

1996 MEDIT felhasználói füzet [MEDIT user's manual]. Budapest: Published by the author.

1997 MiniStat 2.4 verzió. Felhasználói füzet [MINISTAT, version 2.4: User's manual]. Budapest: Published by the author. 